\title{
A Study on the Problems of Light Motor Vehicle Tourist Taxi Operators in Tiruvannamalai District
}

\author{
K. Utharaja
}

\begin{abstract}
Transport Industry plays a pivotal role in the economy of Tamil Nadu and also throughout India. The tourist light motor vehicle transport system is one of the means of road transport which plays a major role in the road sector of tourism development, the people are increasingly dependent on the light motor commercial vehicle like Mahindra van, Motor car and Tata sumo others for a variety of purposes namely, ceremonies, pilgrimage etc., tourist light motor vehicle transport industries have become a catalyst for economic and financial development of other sectors of our economy. The motor carriers are much harder to classify by their service availability than railroads, because a large proportion of them do not offer a general and diversified service to public. First, Motor vehicle carriers are restricted in the amount of territory which they may severe. Grants of authority from regulatory bodies set forth the cities they may connect as the highways ever which they may pass.
\end{abstract}

\section{INTRODUCTION}

$\mathrm{M}$ OTOR vehicle carriers operate on a very small margin. The light motor vehicle transport industry is competitive in many ways and entry is easy if regulatory permission can be gained. It is not uncommon for motor vehicle carriers to expend Ninety Six Percentage of all revenues in expenses of operation. The amount left for profits is extremely small and it can be a negative figure for considerable period. This section is designed to acquaint the reader with the characteristics of the vehicle industry, the importance of highways is some of the current development and regulatory problems in the Motor vehicle carriers yield. Mostly this transport will be create more their problems like operational, Financial and other main future every day. So in these professions, they have to face lot of problems. Among the task operations so offers lot of merchant composition also due to force that this type of problem can be easily solve it.

\section{ESSENTIAL OF TOURISM IN TIRUVANNMALAI}

Some of the important places in the district, which have become famous due to their religious, historical and archaeological importance, are given below. Tiruvannamalai is a well known religious centre and the famous Arunachaleswarar temple, one of the pilgrimage centre for the devote Hindus is here. The deity worshiped here is one of the "Panchalingams" representing one of the "five" elements among the five elements. The Beacon lit during "Karthigai" day in November-December every year over the hill here is

K. Utharaja, PhD Research Scholar, Department of Commerce, CMJ University, Meghalaya.

DOI: 10.9756/BIJIEMS.8344 said to be the symbolic representation of the phenomenon. A great saint Ramana Maharishi established his "Ashramam" here and in recent ways Girivalam. Sathanur Dam built over the Ponnaiyar River. Last attained fame as another holistic spot; a pilgrimage on foot for $14 \mathrm{kms}$ around the hill has assumed Aiquificance every month on the full moonday.

The dam is at a distance of about $30 \mathrm{kms}$ west of Tiruvannamalai town with a well-laid park, beautiful trees, rest houses, etc. It is an ideal picnic centre and draws huge crowds on Sundays and holidays particularly during seasons and Gingee fort is at a distance of about $30 \mathrm{kms}$ east of Tiruvannamalai district. Mainly, the tourist light motor vehicles like Mahindra van, Motorcar, Tata sumo and others are taken on rent by the people who visit the places. So Light Motor Vehicle transport taxis or maxi cabs have become a source of income for many. During the time of festivals a large number of tourist motor taxi vehicles arrive at these places.

\section{Light Motor VehicLE}

Heavy and Light transit forms to as conventional transit modes represent the vast majority of regular public transportation services in most urban areas. "Para transit modes of semi public and public transport which by ownership and types of service are classified between private light motor vehicles transport and conventional transit. Para transit includes several different modes that vary in their operational and physical characteristics. The light motor vehicles are a typical Para transit category in transit service and technological topographical and physical conditions. Most of these transport services and modes play a major but unique role in the towns they serve, they typically carry only a fraction of the total patronage, and yet they often have an important role.

\section{Motor TAXIES}

Motor taxis are also very popular in all big cities where the distance to be covered in individual journey is sufficiently long and passengers have better paying capacity. They prove very convenient and efficient and the local authorities generally fix their rates and fares. The passengers are charged according to the number of miles travelled with are accurately indicated over a meter. Thus the passengers are saved from undesirable exploitation by the driver. So for as the fixation of rates and fares in heavy and light motor transport in India is concerned, the motor vehicle operators do not have to face the problem of joint cost with is inherent in case of railways. "The average Indian operators specialize either in goods or passenger transport. Direct marks like wages, fuel as well as 
repairs etc., are known separately, for earn trip of the vehicle. Moreover in case of small hires, the problem of workshop and overhead expenses does not arise. Further, the phenomenon of falling cost with rising traffic is less frequent for motor transport vehicles than for the railways because it is possible for the operator to ascertain what certain traffic in itself cost him and to quote a rate accordingly.

The organization simplicity that has so far been obtained in road vehicle in India adds to the case of fixing rates on the basis of the cost of service principle. The operating range is small and the factors influencing demand are of local significance, so the motor operator does not feel the necessity to look beyond his own costs for guidance in rate fixing there is no standardized level of operating costs for the whole country or even for any single state. Costs vary even from one route to another according to the bulk of traffic. Wages differ from one place to another. Motor vehicles taxation also differs from one place to another. Besides, there is no uniformity of accountancy practice.

\section{CONTRACT CARRIAGE}

Contract carriage means a Motor vehicle which carriers a passenger or passengers for hire or reward and it is engaged under a contract, whether expressed or implied for the use of such vehicle as a whole for the carriage passengers mentioned there in and entered into by a person with a holder of a permit in relation to such vehicle or any person authorized by him in this behalf on a fixed or an agreed rate or sum.

1. On a time basis, whether or not with reference to any route or distance or

2. From one point to another and in either case, without stopping to pickup or set down passenger not included in the contract any where during the journey and includes.

3. A maxi cab and

4. A Motor cab not withstanding that separate fares are charged for its passengers.

In the case of a contract carriage as defined under the act of contract has got to be the one and it has got to be a prior contract before the Motor vehicle is applied AIR 1991 a 11 300(FB) the definition of contract carriage provided under section 2(7) of the act is exhaustive and takes into fold all types of vehicles which are permitted to ply as contract carriages irrespective of their size in seating capacity. AIR 1991 A11300 (FB) Minibuses cannot pickup individual passengers and contract carriage as given in the Act AIR 1991 A11 300 (FB).

"Light motor vehicle" means a transport maxi cab or Omni bus the gross vehicle weight of either of which or a Motor Car or Tata Sumo or other vehicles or Tractor or Road roller the un-laden weight of any of which does not exceed 7500 kilograms. "Manufacturer" means a person who is engaged in the manufacture of Motor vehicles.

"Maxi cab" means any motor vehicle constructed or adapted to carry more than six passengers, but not more than twelve passengers excluding the driver for hire or reward.
"Motor cab" means any motor vehicle constructed or adapted to carry not more than six passengers excluding the driver for hire or reward.

"Omni bus" means any motor vehicle constructed or adapted more than six persons excluding the driver.

"State carriage" means a motor vehicle constructed or adapted to carry more than six passengers excluding the driver for hire or reward at separate fares or rent paid by or for individual passengers, either for the whole journey or for stages of the journey.

"Tourist vehicle" means a contract carriage constructed or adapted and equipped or maintained in accordance with specifications as may be prescribed in this behalf.

“Traffic signs” includes all signals, warnings, sign posts, and direction posts marking on the road or other devices for the information, guidance or direction of drivers of Motor vehicles.

"Transport vehicle" means a public service vehicle or a good carriage an educational Institution bus or a private service vehicle.

"Medium passenger motor vehicle" means any public service vehicle or private service vehicle or Educational Institution bus other than a Motor cycle, invalid carriage light Motor vehicle or heavy passenger Motor vehicle.

"Motor vehicle or vehicle" means any mechanically propelled vehicle adapted for use upon roads whether the power of propulsion is transmitted there to from an external or internal source and includes a classic to which a body has not been attached and a trailer but does not include a vehicle running upon fixed rails or a vehicle of a special type adapted for use only in a factory or in any other enclosed premises or a vehicle having less than four wheels fitters with engine capacity of not exceeding truly five cubic centimeters. "Route" means a line of travel which specifies the high way which may be traversed by a Motor vehicle between one terminates or another.

"Owner" means a person in whose name a motor vehicle stands registered and where such person is a minor, the guardian of such a minor and in relation to a motor vehicle which is the subject of a hire purchase agreement or an agreement of lease or an agreement of hypothecation the person in possession of the vehicle under that agreement.

"Driver" includes in relation to a motor vehicle, which is drawn by another motor vehicle, the person who acts as a steering man of the vehicle.

"Driving licence" means the licence issued by a competent authority under MV Act 1988, authorizing the person specified there into drive otherwise than as a learner of a Motor vehicle or a Motor vehicle of any specified class or description.

"Learner's Licence" means the license issued by competent authority under the MV Act 1988 authorizing the person specified therein drive as learner a motor vehicle or a motor vehicle of any specified class or description. 
"Heavy passenger vehicle motor" means any public service vehicle or private service vehicle or educational institution bus or Omni bus the gross weight vehicle of any which or a motor car the un laden weight of which exceeds 12000 kilograms.

"Private Service Vehicle" means a motor vehicle constructed or adapted to carry more than six person excluding the driver and ordinarily used by or on behalf of the owners such vehicle for the purpose of carrying persons for or in connection with his trade or business otherwise than for hire or reward but does not include a Motor vehicle used for public purpose.

"Public Service Vehicle” means any other Motor vehicle used or adapted to be used for the carriage of passengers for hire or reward and includes a maxi cab contract carriage and stage carriage.

"Fares" includes sum payable for a season ticket or in respect of the hire of a contract carriage. "Permit" means a permit issued by a state or RTA or an authority prescribed on this behalf under this act authorizing the use of a motor vehicle as a transport vehicle. "Prescribed" means prescribed by rules made this act.

\section{SignificAnCE OF THE STUDY}

The light motor vehicle transport services all over the district in Tamil Nadu mostly, widely required for the day-today transactions of economical and social development and the well being of the people. The important tour service closely related to little difference between constructive and collective passenger thinking about the economic stage and "Industry development in the state/district/town level. The light motor vehicle transport is an efficient and effective more fully recognized to underdeveloped state. The light motor vehicle operation creates self-employment opportunities to getting the financial assistance from commercial banks, financial institutions and private money lenders. The effects of light motor vehicle transportation enable the operators to run their profession with huge investment. The light motor vehicle transport facilities are the most important inevitable factor that help a state or district or town in defiance.

\section{REVIEW OF LITERATURE}

This study has been conducted at different levels by light motor vehicles stand associations, Regional transport office in Tiruvannamalai town, banks and financial institutions (TIIC, TADHCO, LDB, INDIAN BANK) and researcher related it to light motor transport operations and Financial problems at different level of different periods. To study the various sources of financial assistance from new or second hand vehicle purchased from this type of transport system. This task was restricted to the Indian transport development in India. Subsequently, the Indian transport development (ltd), therefore, the government of India in November 1927, appointed the India motor transport committee, under the chairmanship of Mr.M.R.Jayakar, to examine the question of motor transport development in India and to consider how best such development could be financed. The committee further observed that, transport in view of its national importance should be the responsibility of the central government, which should have a motor department to look after them. They argued that the direct income that resulted from transport in terms of duty on fuel price raise to motor transport vehicle went to central revenues. The committee disagreed with the suggestion of the Agricultural Commission for raising loans for transport development Heavy loans were likely to stand in the way of the other nation-building activities of greater importance.

\section{StATEMENT OF THE PROBLEM}

The light motor vehicle tourist taxi operators take on variety of operational problems. The present study is undertaken mainly to bring to focus the myriad varies of problems facing the light motor vehicle transport system in Tiruvannamalai Town. Since no attempt has so far been made to study the economy of light motor vehicle transport, the present study is done to bridge the gap. The light motor vehicle operators face the following problems like financial problem, motor vehicle tax problems, Insurance problems, market competition, and operational problems. Problems with driver and public passengers. Problem with police, problems between owners and drivers. The problem of light motor vehicles owners, the light motor vehicle taxi operators in the aspect of financing and borrowing respectively should be identified, analyzed and possible solutions be suggested for solving them.

\section{OBJECtIVES OF THE STUDY}

This study attempts

i. To find out the economic conditions and cost of operation of light motor vehicle transport in Tiruvannamalai town.

ii. To identify their problems and

iii. To suggest possible remedial measures and suggestions.

\section{Methodology}

This is an analytical study. The researcher conducted a survey by interviewing tourist light motor vehicle taxi ownerscum drivers, and drivers. The Regional transport authorities like officials of Regional transport office, various stand associations and prepared an adhoc of schedule of questionnaire. Thus the primary and secondary data are used in the analysis of study. Requisite secondary data were collected from Tiruvannamalai collectorate, Commercial Banks and Financial institutions like TIIC, Indian Bank, TAHDCO,IOB, LDB, and various types regarding companies, transport journals, transport books, motor vehicle statistics of India, federation of owner associations in Tiruvannamalai and Tourism development corporation in Dharmapuri. A pilot study is first made in the Tiruvannamalai Town area covering hundred tourist light motor vehicle Taxi operators to the nature of response from them and the adequate of the framework of the questions included. On the basis of the experience gained in the pilot study, the schedule have been amended and used. The period of study covers. 
Light Motor Vehicle Taxi Operators in Tiruvannmalai Distirct

Preliminary discussions were held with light motor vehicle owners, drivers, and various staff members in banks, financial institutions like TIIC, TAHDCO, Indian Bank, IOB and LDB detailed questionnaire was prepared to interview and collect information from taxi operators in Tiruvannamalai town. Questions were sent to collect demographic facts such as the Nature and Size of the families, Age-group, Educational qualifications, Experience, Individuals income, expenditure incurred for maintenance of vehicle, repayment of debts, rate of interest on debts, overall debt burden, the life style caste pattern of taxi operators, motivation for light motor vehicle driving profession, trips problems, their participation in vehicle Association, entertainment of the operators and many other useful data for the analysis of this study.

\section{CONCLUSION}

Field work was carried from March to August 2007 for a period of four months. The researcher got himself well acquainted with the taxi owners and drivers, taxi stand associations. Interviews were carried on with the respondents i.e., the light motor vehicle taxi owners cum drivers and drivers. In the conventional manner and to the convenience of them. On an average it book about 15 to 30 minutes for an interview. The researcher faced many difficulties in conducting the interview. Even while conducting the interview some passenger will engage the owner of light motor vehicle like van, car, sumo and others as such, the researcher used to accompany some of the alone van, car, sumo operators and others along with users and continued and completed the interview. Some taxi operators or drivers simply refused to respond to the request of the researcher. Some respondents happily replied with the hope of getting some benefits from the Government in near future.

In the field survey, the bio-data of the taxi operators such as educational qualifications, mother tongue, age, experience, employments earned personal particulars such as married, bachelors, individual income etc are their daily trip problems with the passengers, police, drivers Vs owners, passengers and drivers, judiciary, the light motor vehicles users were collected, complied and used in the study and wherever expressed in the form of tables.

The field work was carried over in different parts of the town such as Taxi stands, travels places, broker offices and Regional transport office.

\section{REFERENCES}

[1] P.T. McElthiney and C.L. Hilton, "Introduction to Logistics and Traffic Management”, los Angeles, Dubuque: Com. C.Brown co. Publishers, Pp. 105-119, 1968.

[2] B. Pattabbiraman, "Tamilnadu motor vehicle Act-with central and Tamilnadu central notifications as Amendes. upto Date and Case Law”, Vidya house, Chennai, Pp. 39-55, 1997.

[3] Flash report for the month of Feb-Mar 2001, "Motor Journal the leader in auto electronic genuine spares", $\operatorname{KAME(R).~}$

[4] “Total Registered motor vehicle in India as on 31 march 1996-1997", Motor transport statistics of India 1977.

[5] "Compendium of Environment Statistics", central statistical organization, department of statistics ministry of planning and program implementation, Government of India, New Delhi, 1986.
[6] Regional Transport office, Tiruvannamalai, 2001.

[7] M.T. Farris, “The Regulation of motor carrier”, Aridona road runner, Pp. 16-17, 1970.

[8] Bhatangar, K.P. Satish Bahadur and D.N. Agarwal, "Transport in Modern India”, 10-Kishore publishing house, 1961.

[9] J.B. Lansing, "Transport and economic policy", The Free press Newyork Collier-Macmillan Lted, 1996. 